\title{
Development of an in vitro pre-mRNA splicing assay using plant nuclear extract
}

\author{
Mohammed Albaqami and Anireddy S. N. Reddy*
}

\begin{abstract}
Background: Pre-mRNA splicing is an essential post-transcriptional process in all eukaryotes. In vitro splicing systems using nuclear or cytoplasmic extracts from mammalian cells, yeast, and Drosophila have provided a wealth of mechanistic insights into assembly and composition of the spliceosome, splicing regulatory proteins and mechanisms of pre-mRNA splicing in non-plant systems. The lack of an in vitro splicing system prepared from plant cells has been a major limitation in splicing research in plants.

Results: Here we report an in vitro splicing assay system using plant nuclear extract. Several lines of evidence indicate that nuclear extract derived from Arabidopsis seedlings can convert pre-mRNA substrate (LHCB3) into a spliced product. These include: (1) generation of an RNA product that corresponds to the size of expected mRNA, (2) a junction-mapping assay using S1 nuclease revealed that the two exons are spliced together, (3) the reaction conditions are similar to those found with non-plant extracts and (4) finally mutations in conserved donor and acceptor sites abolished the production of the spliced product.
\end{abstract}

Conclusions: This first report on the plant in vitro splicing assay opens new avenues to investigate plant spliceosome assembly and composition, and splicing regulatory mechanisms specific to plants.

Keywords: Arabidopsis, Pre-mRNA, Splicing, In vitro splicing, Plant in vitro splicing

\section{Background}

Shortly after the discovery of introns in 1977, different groups developed the mammalian cell-free system (in vitro), using nuclear or cytoplasmic extracts, which were competent for pre-mRNA splicing [1-3]. Subsequently, the preparation of efficient splicing extracts and the in vitro splicing assay have been adapted to other organisms such as budding yeast (Saccharomyces cerevisiae) and fruit flies (Drosophila melanogaster) [4, 5]. The development of mammalian, yeast, and Drosophila in vitro systems to study pre-mRNA splicing has provided essential insights into spliceosome assembly, its composition and splicing mechanisms in non-plant systems. The characterization of the splicing two-step trans-esterification reaction, pre-mRNA splicing intermediates, and the formation of final mature mRNA and lariat structure of intron have all been revealed by in vitro

\footnotetext{
*Correspondence: reddy@colostate.edu

Department of Biology and Program in Cell and Molecular Biology,

Colorado State University, Fort Collins, CO 80523-1878, USA
}

splicing studies [3, 6]. Furthermore, in vitro splicing combined with immunodepletion has long been used to determine the roles of spliceosomal components, such as small nuclear ribonucleic proteins (snRNP) [7, 8]. Several other splicing regulators were characterized by their ability to promote the in vitro splicing assay $[9,10]$. Furthermore, the formation of spliceosomal complexes and their stepwise assembly pathway have been deduced in vitro by native (nondenaturing) agarose/polyacrylamide gel electrophoresis [11-13]. Additionally, many in vitro biochemical splicing studies have allowed purification of spliceosomes and provided a wealth of information on the spliceosome's composition, its structures, and the structure conformational dynamics of spliceosomal complexes [13-21]. The identification of additional splicing regulatory cis-elements, such as splicing enhancers or silencers and their cognate factors, has also been expedited by studies using in vitro biochemical assays [22-27]. The in vitro splicing assay has also been a valuable technique for dissecting abnormal splicing events, 
which cause human genetic disease, and in developing new therapeutic approaches for human disease [2, $28]$. Finally, the in vitro splicing assay has been used to evaluate molecules with splicing inhibitory functions, such as spliceostatin A [29]. These are some examples to illustrate how in vitro splicing assays have contributed to important information on regulatory mechanisms of gene expression. The in vitro splicing systems have been, and will continue to be, indispensable tools for studying the mechanism of splicing.

As in animals, pre-mRNAs from a majority (over $80 \%$ ) of plant genes contain non-coding sequences and are processed to generate mature mRNAs [30, 31]. Recent studies indicate that the developmental and environmental cues can reprogram gene expression in plants by regulating post-transcriptional processes, especially pre-mRNA splicing [31-38]. However, many aspects of pre-mRNA splicing in plants are yet to be elucidated. Furthermore, the composition of the plant spliceosome and its assembly intermediates are currently undefined $[39,40]$. Thus, the study of pre-mRNA splicing in plants requires innovative approaches, which will greatly empower this field of research.

In spite of the absence of an in vitro plant-splicing system, efforts have been made to identify plant spliceosomal components. Bioinformatics analyses using sequence similarity have identified the core components of the plant spliceosome, including five snRNAs and several orthologs of known spliceosomal proteins [40-44]. Likewise, the highly conserved sequences at the $5^{\prime}$ splice site $\left(5^{\prime} \mathrm{ss}\right), 3^{\prime}$ splice site $\left(3^{\prime} \mathrm{ss}\right)$, polypyrimidine tract and branch point sequence (BPS) are similar between plants and animals [31]. These similarities and some reports on splicing of plant introns in mammalian splicing extracts $[45,46]$ suggest similar basic mechanisms of intron processing across eukaryotic systems, but there are also numerous indications of plant-specific splicing regulatory mechanisms. For example, animal introns cannot be processed or animal transcripts are aberrantly spliced in plant systems $[47,48]$, the average sizes of plant introns are shorter than their mammalian counterparts [40], and analysis of proteins similar to mammalian spliceosomal proteins indicates that there is almost twice the number of plant splicing factors compared to human splicing factors $[40,44]$. Other studies have also shown that plants and animals use different mechanisms to recognize splice sites, especially $3^{\prime}$ splice sites [49-52]. Furthermore, comparative analysis of alternative splicing (AS) events between plants and animals has revealed that intron retention is the predominant mode of AS in plants [53,54], whereas exon skipping is the predominant mode in animals [55]. Although the pre-mRNA splicing mechanisms in plants are poorly understood, based on the reasons cited above it is likely that the mechanisms of recognition of introns and exons involve both similar and plant-specific mechanisms.

The development of in vitro systems to study RNArelated mechanisms in plants is limited and challenging $[40,56,57]$. An in vitro pre-mRNA splicing system to uncover plant splicing regulatory mechanisms has long been awaited [39, 40]. Therefore, despite difficulties inherent to plant cells, here we describe our efforts to develop an in vitro system for plant pre-mRNA splicing using nuclear extract (NE) prepared from Arabidopsis seedlings. We present a detailed procedure for the preparation of the NE and a subsequent in vitro splicing reaction using a plant pre-mRNA substrate containing a single intron from light-harvesting chlorophyll B-binding protein 3 ( $L H C B 3)$. We show that plant NE is capable of converting $L H C B 3$ pre-mRNA substrate to the size of expected mRNA. This is the first step toward establishing a plant-derived in vitro pre-mRNA splicing assay. This study opens new avenues to investigate spliceosome assembly and composition, splicing regulatory mechanisms specific to plants, and thereby enhances the overall understanding of post-transcriptional gene regulatory mechanisms in eukaryotes.

\section{Methods \\ Arabidopsis nuclear extract preparation}

The nuclear extract preparation method presented here is a modification of protocols described previously [58-60]. For plant material preparation, seeds $(50 \mathrm{mg})$ of Arabidopsis thaliana ecotype Columbia-0 (Col-0) were surface-sterilized with $70 \%$ ethanol followed by $15 \%$ bleach and stratified for 3 days at $4{ }^{\circ} \mathrm{C}$. Then, seeds were placed into $100 \mathrm{ml}$ of Murashige and Skoog (MS) medium (1× MS basal salts, $1 \mathrm{ml} / \mathrm{l}$ MS vitamin solution, and $1 \%$ sucrose, $\mathrm{pH}$ 5.7) in a $250 \mathrm{ml}$ flask and moved to a growth chamber. Seedlings were grown in a flask on a shaker at $150 \mathrm{rpm}$ in dark at $24{ }^{\circ} \mathrm{C}$ for 4 days. Four-day-old seedlings were harvested, rinsed three times with Nanopure water, and excessive water was removed using a few layers of Kimwipes. Afterwards, the seedlings were weighed, directly frozen in liquid $\mathrm{N}_{2}$, and stored at $-80^{\circ} \mathrm{C}$.

For nuclear protein preparation, $5 \mathrm{~g}$ of etiolated seedlings were ground into a fine powder in liquid nitrogen. Subsequently, the sample was homogenized in $25 \mathrm{ml}$ of Honda buffer (1.25\% Ficoll 400, 2.5\% Dextran T40, $0.44 \mathrm{M}$ sucrose, $10 \mathrm{mM} \mathrm{MgCl}_{2}, 0.5 \%$ Triton X-100, 20 mM HEPES KOH, pH 7.4, 5 mM DTT, 1 mM PMSF, and $1 \%$ protease inhibitor cocktail [Sigma-Aldrich, St. Louis, MO, USA; catalog number: P9599]) for $15 \mathrm{~min}$ on ice, with gentle mixing every minute. The homogenate was filtered through two layers of Miracloth into a $50 \mathrm{ml}$ Corex tube. Then the residue left behind on the 
Miracloth was washed with $25 \mathrm{ml}$ ice-cold Honda buffer, and then the filtration step was repeated and collected into the same Corex tube. The filtrate (total $50 \mathrm{ml}$ ) was centrifuged at $2000 \mathrm{~g}$ for $15 \mathrm{~min}$ at $4{ }^{\circ} \mathrm{C}$. The supernatant was discarded and the pellet resuspended in $15 \mathrm{ml}$ ice-cold Honda buffer, then incubated on ice for $15 \mathrm{~min}$ with gentle mixing every minute. It is not recommended to pipet up and down when mixing, as this can disrupt the nuclei; instead, a camel-hair brush should be used to resuspend the nuclei pellet. After complete resuspension, the sample was centrifuged at $1500 \mathrm{~g}$ for $15 \mathrm{~min}$ at $4{ }^{\circ} \mathrm{C}$. This washing step was repeated two times. The pellet was then resuspended in $15 \mathrm{ml}$ ice-cold washing buffer (20 mM HEPES KOH, pH 7.9, $100 \mathrm{mM} \mathrm{KCl,} 0.2 \mathrm{mM}$ EDTA, 10\% (v/v) glycerol, $1 \mathrm{mM}$ DTT, $1 \mathrm{mM}$ PMSF, and $1 \%$ protease inhibitor cocktail [Sigma-Aldrich, St. Louis, MO; catalog number: P9599]) for 15 min on ice, mixed gently every minute. It is also not recommended to mix by pipetting here. After complete resuspension, the sample was centrifuged at $1500 \mathrm{~g}$ for $15 \mathrm{~min}$ at $4{ }^{\circ} \mathrm{C}$. The nuclei pellet was then resuspended in $0.5 \times(150 \mu \mathrm{l})$ icecold nuclei swelling buffer (50 mM Tris- $\mathrm{HCl}(\mathrm{pH} 7.9)$, $10 \mathrm{mM}$ 2-mercaptoethanol, 20\% glycerol, $5 \mathrm{mM} \mathrm{MgCl}_{2}$, $0.44 \mathrm{M}$ sucrose, $1 \mathrm{mM}$ PMSF, and $1 \%$ protease inhibitor cocktail [Sigma-Aldrich, St. Louis, MO, USA; catalog number: P9599]) and transferred to a $1.5 \mathrm{ml}$ microcentrifuge tube, then incubated at $4{ }^{\circ} \mathrm{C}$ for $30 \mathrm{~min}$ with gentle rocking. The extract was then centrifuged for $30 \mathrm{~min}$ at maximum speed $(16,000 g)$ at $4{ }^{\circ} \mathrm{C}$ and the supernatant removed to a new $1.5 \mathrm{ml}$ microcentrifuge tube. Then, the $\mathrm{NE}$ was distributed into $50 \mu \mathrm{l}$ aliquots, flash-frozen in liquid nitrogen and stored at $-80{ }^{\circ} \mathrm{C}$ for in vitro splicing assay.

\section{DNA templates and in vitro pre-mRNA synthesis}

For in vitro pre-mRNA synthesis, DNA templates were amplified by PCR from Arabidopsis genomic DNA, using a gene-specific forward primer plus SP6 promoter sequence and reverse primer plus an adaptor sequence, which could be used for specific amplification of the spliced product. PCR products of the correct size were then gel-purified using the Thermo Scientific GeneJET Gel Extraction Kit (Thermo Fisher Scientific, Waltham, MA, USA; catalog number: K0691). Purified DNA templates were quantified using a NanoDrop 1000, and approximately $0.250 \mu \mathrm{g}$ of amplified DNA template was used for in vitro transcription. To generate mutations at conserved splicing sites, DNA template sequences with desired sequences were synthesized at Integrated DNA Technologies, Inc. (Coralville, IA, USA; https://www. idtdna.com).

$\left[{ }^{32} \mathrm{P}\right]$-labelled pre-mRNA substrates were prepared using an in vitro transcription system as described previously in [61]. The pre-mRNA substrates were internally labeled with $45 \mu \mathrm{Ci}$ of $\left[\alpha_{-}{ }^{32} \mathrm{P}\right]$ UTP (800 Ci mmol ${ }^{-1}$, PerkinElmer, Waltham, MA, USA) using SP6 RNA polymerase (Fermentas, Thermo Fisher Scientific, Waltham, MA, USA; www.fermentas.com) in the presence of $500 \mu \mathrm{M}$ ATP and CTP, $50 \mu \mathrm{M}$ GTP and UTP, $50 \mu \mathrm{M}$ cap analog $\left({ }^{7 \mathrm{~m}} \mathrm{GpppG}\right)$, and $20 \mathrm{U}$ RNase inhibitor. In vitro synthesized $\left[{ }^{32} \mathrm{P}\right]$-labelled pre-mRNAs with the correct size were gel-purified using TNS solution (25 mM Tris- $\mathrm{HCl}(\mathrm{pH} 7.5), 400 \mathrm{mM} \mathrm{NaCl}, 0.1 \%$ SDS) for overnight at room temperature. Radioactive pre-mRNAs were measured using a liquid scintillation counter (Tri-Carb Liquid Scintillation Counter, PerkinElmer, Waltham, MA, USA); 25,000 CPM ( $20 \mathrm{fmol})$ of $\left[{ }^{32} \mathrm{P}\right]$-labelled pre-mRNA substrates was used for in vitro splicing reactions unless otherwise specified (see figure legends).

\section{In vitro splicing}

Unless otherwise specified, in vitro splicing reactions $(25 \mu \mathrm{l})$ contained $1 \mathrm{mM}$ ATP, $20 \mathrm{mM}$ creatine phosphate (CP), 10 U RNase inhibitor, $1 \mathrm{mM}$ DTT, $72.5 \mathrm{mM}$ KOAc, 25,000 CPM ( $20 \mathrm{fmol})\left[{ }^{32} \mathrm{P}\right]$-labelled pre-mRNA, and $50 \%$ NE. Reactions were incubated at $30{ }^{\circ} \mathrm{C}$ for the times indicated in figure legends. Subsequently, $175 \mu \mathrm{l}$ of proteinase $\mathrm{K}$ master mix $(1 \times$ proteinase $\mathrm{K}$ buffer, $0.25 \mathrm{mg} /$ $\mathrm{ml}$ glycogen, $0.25 \mathrm{mg} / \mathrm{ml}$ proteinase $\mathrm{K}$, and sterile water) was added, and the solution incubated at $37{ }^{\circ} \mathrm{C}$ for $20 \mathrm{~min}$. Afterward, RNA was purified by adding an equal volume of phenol:chloroform, precipitating with 2.5 volumes of $100 \%$ ice-cold ethanol, and air-drying the isolated pellet for $5 \mathrm{~min}$ [62]. Finally, RNA samples were dissolved with formamide/EDTA stop dye (formamide with $0.1 \%$ bromophenol blue, $0.1 \%$ xylene cyanol, and 2 mM EDTA).

\section{Visualization of splicing products}

Purified RNA from in vitro splicing reactions was analyzed by fractionation on a $6 \%$ polyacrylamide-urea gel as described previously [62]. RNA samples were heated at $95{ }^{\circ} \mathrm{C}$ for $3 \mathrm{~min}$, and loaded onto a pre-run gel. The gel was run at $200 \mathrm{~V}$ for $3 \mathrm{~h}$. Subsequently, the gel was transferred onto Whatman paper and dried for $2 \mathrm{~h}$ using a Bio-Rad Gel Dryer at $80{ }^{\circ} \mathrm{C}$ with suction. The gel was then exposed to a phosphor-imaging screen overnight, and imaged using a STORM 840 imager (Molecular Dynamics, GE Healthcare, Little Chalfont, United Kingdom; www.gehealthcare.com).

\section{S1 nuclease protection assay}

For the S1 nuclease protection assay, in vitro spliced RNA (spliced RNA) was gel-purified as described above. The spliced product from at least three samples was pooled 
together. DNA oligo (50 nt, $100 \mu \mathrm{M}$ ) with sequence complementary to the exon/exon junction was hybridized to the purified RNA in S1 hybridization buffer (80\% formamide, $40 \mathrm{mM}$ PIPES (pH 6.4), $500 \mathrm{mM} \mathrm{NaCl}, 1 \mathrm{mM}$ EDTA) for $2 \mathrm{~h}$ at room temperature after denaturing at $95{ }^{\circ} \mathrm{C}$ for $5 \mathrm{~min}$ [63]. Subsequently, total hybridized $\left[{ }^{32} \mathrm{P}\right]$-labelled RNA/oligo DNA was digested with S1 nuclease (100U) (Promega, Madison, WI; catalog number: M5761) in $1 \times$ S1 nuclease buffer (provided with the enzyme) for $1 \mathrm{~h}$ at $37{ }^{\circ} \mathrm{C}$. The undigested $\left[{ }^{32} \mathrm{P}\right]$-labelled RNA was purified by phenol:chloroform extraction and visualized as described above.

\section{Results}

\section{Arabidopsis NE processed $L H C B 3$ pre-mRNA to produce an expected size mRNA}

Generally, in vitro splicing reactions are conducted using NE prepared from HeLa cells; however, there are reports of NEs from other cells, such as Drosophila Kc cells, also being used [64]. The quality of NE is a vital factor for a successful and efficient in vitro splicing assay [64]. Therefore, we aimed first to develop a method for the preparation of NE from Arabidopsis etiolated seedlings to use in in vitro splicing assays. We tried three different modified methods of NE preparation from either etiolated or light-grown seedling. Only one of these methods that is modified from different protocols [58-60] using etiolated seedlings was found to be competent in splicing a pre-mRNA. This NE preparation protocol is described in detail in the methods section (Additional file 1: Figure S1). The other two modified methods that use (1) hexylene glycol-based buffers followed by Percoll density gradients [58] or (2) Honda buffer method [65] either did not show splicing of pre-mRNA or showed very weak splicing activity in our hands. Hence, these methods are not described in detail.

To test this Arabidopsis NE for in vitro splicing activity, we used a pre-mRNA substrate that contained a single intron flanked with two truncated exons from Arabidopsis gene light-harvesting complex B3 (LHCB3) (Fig. 1a, b and Additional file 2: Figure S2). The $L H C B 3$ pre-mRNA substrate carried an $82 \mathrm{nt} 5^{\prime}$ exon, $64 \mathrm{nt}$ intron, and 51 nt of $3^{\prime}$ exon plus a $22 \mathrm{nt}$ adaptor sequence for a total length of 219 nt (Fig. 1c). The $\left[{ }^{32} \mathrm{P}\right]$-labelled $L H C B 3$ premRNA was incubated at $30{ }^{\circ} \mathrm{C}$ in Arabidopsis NE for 0, 90 , or $180 \mathrm{~min}$. The reaction products were isolated and analyzed by $6 \%$ denaturing polyacrylamide gel (Fig. 2a). We did not observe any [ $\left.{ }^{32} \mathrm{P}\right]$-labelled spliced RNA at 0 min incubation time; however, at 90 and 180 min there were multiple $\left[{ }^{32} \mathrm{P}\right]$-labelled species smaller than the premRNA substrate. The predicted spliced mRNA is $155 \mathrm{nt}$ long (Fig. 1c). Certainly, a 155 nt RNA, the expected size of spliced mRNA, was observed after $90 \mathrm{~min}$, and this product was accumulated to a higher level after $180 \mathrm{~min}$ (Fig. 2a). We also generated a $\left[{ }^{32} \mathrm{P}\right]$-labelled marker mRNA from an $L H C B 3 \mathrm{cDNA}$ template $\left(\mathrm{M}^{*}\right)$ for comparison with the in vitro product. In addition, we observed other RNA species (indicated with asterisks) consistently, which are likely to correspond to the pre-mRNA splicing intermediates or degradation products (Fig. 2a). This finding suggests the possible in vitro splicing of $L H C B 3$ pre-mRNA using Arabidopsis NE.

\section{Heating of Arabidopsis NE inactivated in vitro splicing reaction}

Pre-mRNA splicing is mediated via the spliceosome, which is a large and dynamic machine containing five snRNPs and numerous proteins [13]. It has been reported that heat-treated NE prepared from HeLa cells or yeast whole cell extract was unable to form a functional spliceosome and splice pre-mRNA in vitro $[66,67]$. Therefore, we incubated the Arabidopsis NE at $90{ }^{\circ} \mathrm{C}$ for $3 \mathrm{~min}$, and then tested its splicing activity with $\left[{ }^{32} \mathrm{P}\right]$-labelled LHCB3 pre-mRNA substrate. While the untreated NE converted the input pre-mRNA to the expected product, heat-treated NE was unable to do so (Fig. 2b). In agreement with non-plant splicing extracts, these results suggest that the Arabidopsis NE contains heat-sensitive components that are required for producing the splicing product.

\section{Spliced product increased with increasing NE concentration}

In order to determine the effect of NE concentration on the production of the spliced mRNA, a range of NE concentrations from 0 to $50 \%(\mathrm{v} / \mathrm{v})$ were tested while maintaining consistent volume and chemical composition of the reactions by adding an appropriate amount of NEcontaining buffer. Indeed, the production of the splicing product increased with increasing $\mathrm{NE}$ concentration (Fig. 2c). In addition, it seems that $30 \%(\mathrm{v} / \mathrm{v})$ is an optimal NE concentration for this in vitro splicing assay. Thus, these results support that the appearance of the spliced mRNA is dependent on the concentration of proteins present in the NE.

\section{Characterization of spliced product using S1 nuclease protection assay}

To determine whether the $\left[{ }^{32} \mathrm{P}\right]$-labelled $L H C B 3$ premRNA substrate was accurately spliced in vitro, the spliced product was analyzed by S1 nuclease protection assay. For this assay, we used a DNA oligonucleotide $(50 \mathrm{nt})$ probe designed to pair with the exon junction that is predicted to be joined together during in vitro splicing (Fig. 3a). The $\left[{ }^{32} \mathrm{P}\right]$-labelled spliced product generated in the in vitro assay was gel-purified 
a DNA template design
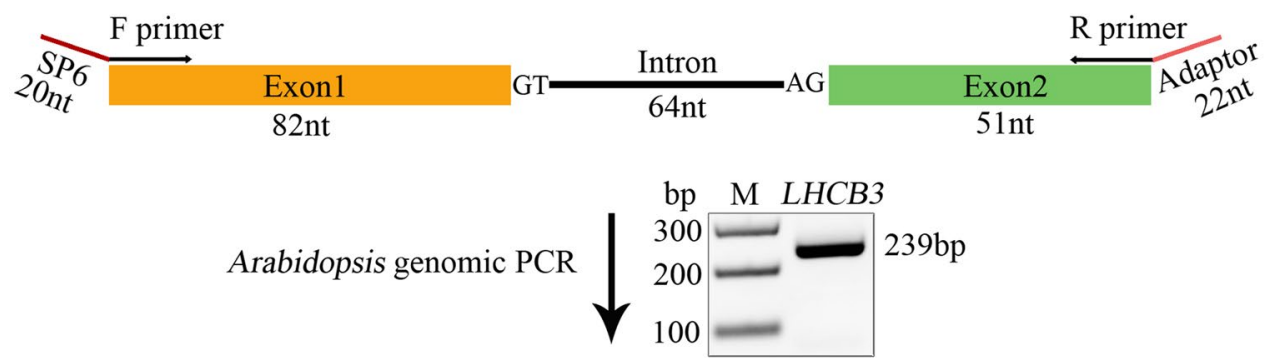

b DNA template

GT<smiles>[3H]C[3H]</smiles>

$\mathrm{AG}$

$239 \mathrm{bp}$

c In vitro pre-mRNA splicing

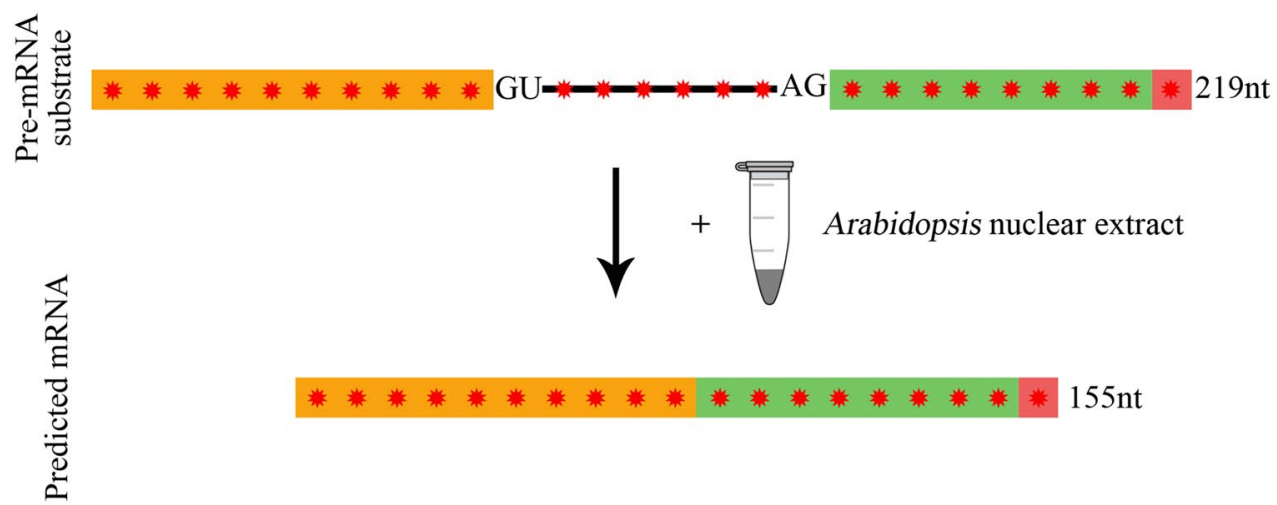

Fig. 1 Preparation of $L H C B 3\left[{ }^{32} \mathrm{P}\right]$-labeled pre-mRNA substrate used for in vitro splicing assay. a Top, a schematic representation of a region of Arabidopsis LHCB3 (AT5G54270) gene used to prepare DNA template to synthesize pre-mRNA substrate. A portion of the third and fourth exons (Orange and green boxes, respectively, labeled as exon 1 and exon2) and second intron (black line, labeled as intron) was used. F primer, forward primer with SP6 promoter sequence (red line), R primer reverse primer with an adaptor sequence (red line). Bottom, PCR fragment amplified with F and R primers using Arabidopsis genomic DNA. The PCR product was gel purified and used for in vitro transcription reaction. $\mathbf{b}$ Top, schematic of DNA template that was used to synthesize [ $\left.{ }^{32} \mathrm{P}\right]$-labeled $L H C B 3$ pre-mRNA substrate. Bottom, A representative autoradiogram of in vitro $\left.{ }^{32} \mathrm{P}\right]$-labeled LHCB3 pre-mRNA substrate. c Description of in vitro splicing assay. Top, Schematic representation of labeled LHCB3 pre-mRNA substrate used for in vitro splicing assay. Bottom, predicted mRNA after in vitro splicing of pre-mRNA substrate. Sizes of intron, exons, pre-mRNA, and predicted mRNA are indicated. Red asterisks indicate [ $\left.{ }^{32} \mathrm{P}\right]$-nucleotides in RNA

and at least three samples pooled together to enhance the amount of RNA present. Probes were allowed to hybridize with the purified RNA sample. In addition, the probe was also hybridized with the unspliced $\left[{ }^{32} \mathrm{P}\right]$-labelled $L H C B 3$ pre-mRNA substrate as a negative control. Subsequently, the hybridized molecules were digested with a single-strand nucleic acid-specific S1 nuclease. The S1-resistant products were then separated on a denaturing polyacrylamide gel and visualized by autoradiography (Fig. 3b). The estimated size of the protected sequence is $\sim 50 \mathrm{nt}$ long, and indeed, the predicted in vitro splice product generated an S1-resistant product with approximately size of $\sim 50 \mathrm{nt}$. Conversely, the unspliced pre-mRNA produced smaller products including sizes of around $25 \mathrm{nt}$. These results suggest that the $\left[{ }^{32} \mathrm{P}\right]$-labelled $L H C B 3$ pre-mRNA is accurately 
Fig. 2 In vitro splicing assays. a In vitro splicing assay with the Arabidopsis $L H C B 3$ pre-mRNA substrate. Radioactive $L H C B 3$ pre-mRNA substrate was synthesized in vitro with a DNA template using SP6 RNA polymerase (see Fig. 1b) as described in materials and methods. ${ }^{32} \mathrm{P}$-labeled $\angle H C B 3$ pre-mRNA substrate $(25,000 \mathrm{cpm})$ was incubated with nuclear extract from Arabidopsis etiolated seedlings at $30^{\circ} \mathrm{C}$ as described in materials and methods. Samples were withdrawn at intervals (0, 90 and $\left.180 \mathrm{~min}),{ }^{32} \mathrm{P}\right]$-RNA was extracted and analyzed by electrophoresis on a $6 \%$ polyacrylamide gel containing $7 \mathrm{M}$ urea. The gel was dried and exposed to a phosphor-imaging screen. $\mathbf{b}$ Heat-inactivation of Arabidopsis NE abolished the production of a spliced product NE from Arabidopsis etiolated seedlings was incubated at $90^{\circ} \mathrm{C}$ for 3 min or kept on ice (as a control) were used for splicing assays at $30^{\circ} \mathrm{C}$ with the LHCB3 $\left[{ }^{32} \mathrm{P}\right]$-pre-mRNA. Samples were withdrawn at different time points (0,90, and $\left.180 \mathrm{~min}),{ }^{32} \mathrm{P}\right]-$ RNA was extracted and analyzed as described above. $\mathbf{c}$ The spliced product is increased with increasing nuclear extract concentration. In vitro splicing of [ $\left.{ }^{32} \mathrm{P}\right]$-labeled LHCB3 pre-mRNA substrate $(25,000 \mathrm{cpm})$ was carried out at $30^{\circ} \mathrm{C}$ in $25 \mu$ l reaction volume containing different concentrations $0-50 \%(\mathrm{~V} / \mathrm{v})$ of nuclear extract as described in materials and methods. All reactions were stopped after three hours; $\left.{ }^{32} \mathrm{P}\right]-\mathrm{RNA}$ was extracted and analyzed as described above. M indicates [ $\left.{ }^{32} \mathrm{P}\right]$-labeled RNA markers synthesized in vitro using RNA Century ${ }^{\text {TM }}$-Plus Marker Templates (Applied Biosystems, AM7782). $M^{*}$ lane contains [ $\left.{ }^{32} \mathrm{P}\right]$-labeled LHCB3 pre-mRNA, spliced mRNA, and exon1. Schematic diagrams on the right show premRNA, spliced mRNA and exon 1 and their sizes. One of the $\left.{ }^{32} \mathrm{P}\right]-\mathrm{RNA}$ products formed in in vitro splicing assay corresponds to the size of spliced [ $\left.{ }^{32} \mathrm{P}\right]$-mRNA marker, suggesting that it could be a spliced product. The asterisks indicate the potential splicing intermediates. Other [ $\left.{ }^{32} \mathrm{P}\right]-R N A$ products could be another pre-mRNA splicing intermediates and/or degradation products

spliced in vitro to generate the authentic mRNA sequence spanning the $L H C B 3$ exon1-exon2 junction.

\section{Mutations in conserved splice sites modulate the production of spliced product}

During the pre-mRNA splicing process, the spliceosome assembles around the $5^{\prime} \mathrm{ss}$ at the beginning of an intron and the $3^{\prime}$ ss at the end of that intron [14]. It is well-established that each splice site in plants and animals consists of consensus sequences, and these include almost invariant dinucleotides: GT at the $5^{\prime}$ ss and AG at the $3^{\prime}$ ss [31]. In vitro mutation analysis of the conserved 5'ss GT revealed that these mutations could modulate splice site choices and reduce the rate of two exons ligating [68]. Therefore, we aimed here to investigate if substitution mutations of 5 'ss GT in the LHCB3 pre-mRNA substrate affect the production of its in vitro spliced product. To this end, we generated a $L H C B 3$ pre-mRNA substrates carrying substitution mutation of $5^{\prime}$ ss GT to AC (Mutant 1, M1) (Fig. 4a, Additional file 3: Figure S3). In addition, since a previous study showed that mutation of the 5 ss GU did not prevent cleavage in 5 'ss region, but only affected the production of spliced mRNA [68], we also included another mutated pre-mRNA substrate (Mutant 2, M2). In this substrate, both $5^{\prime}$ ss and $3^{\prime}$ ss conserved

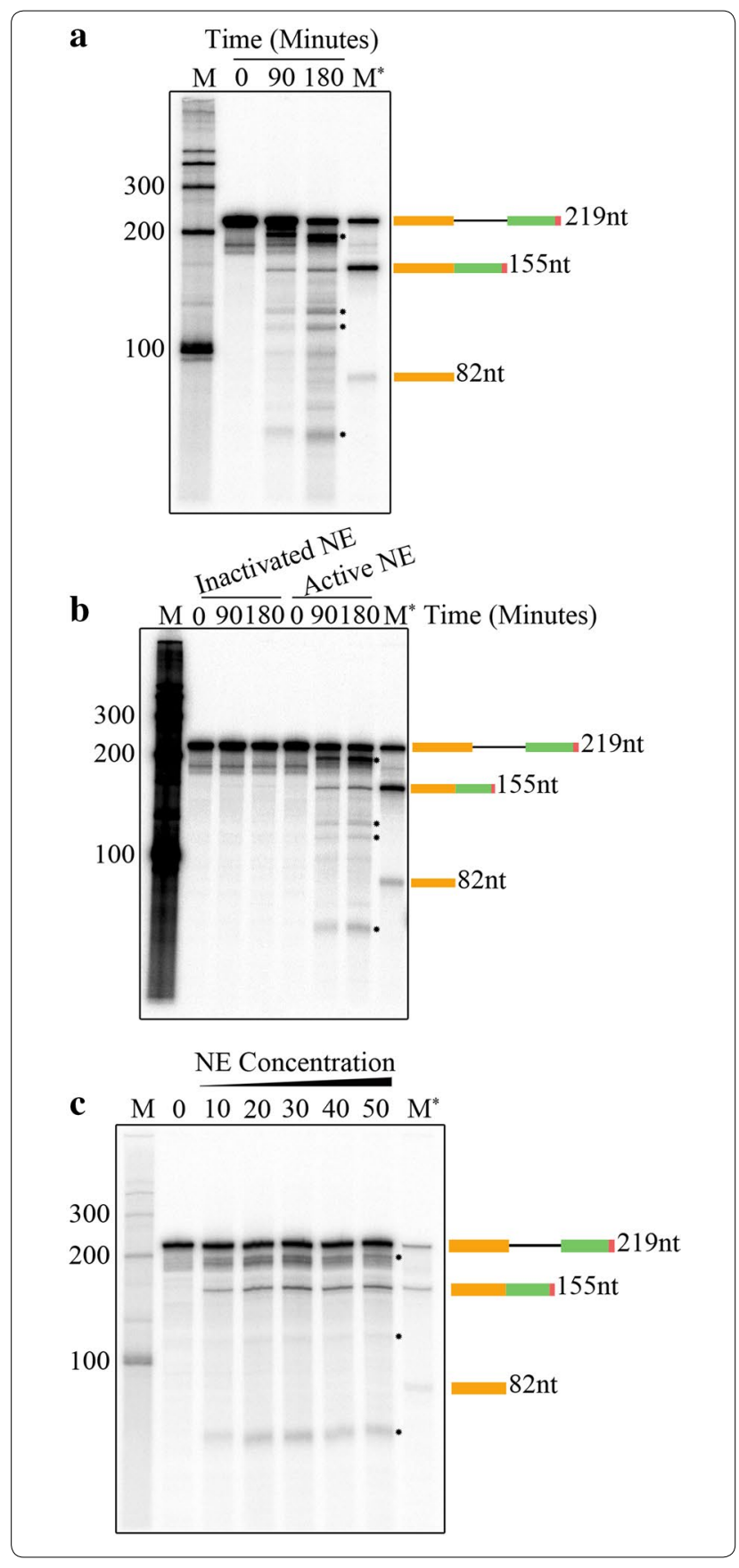

sequences $(-3,+5)$ are changed [31]. In vitro splicing assays using these pre-mRNA substrates revealed that mutations of the conserved splice site sequences modulate the in vitro production of $L H C B 3$ spliced mRNA (Fig. 4b). In agreement with a previous study [68], M1 did not completely abolish the production of spliced mRNA; however, this mutation clearly reduced the generation of the spliced mRNA. Interestingly, M2 completely eliminated the production of the expected product, and 


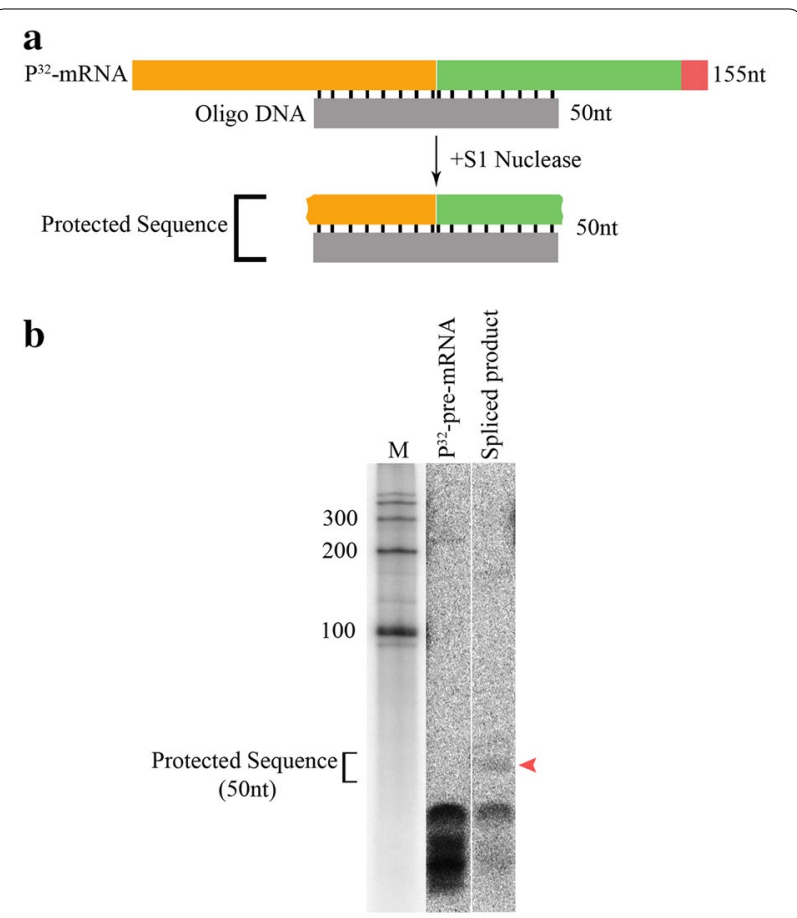

Fig. 3 Characterization of the spliced product using S1 nuclease. a Schematic representation of S1 nuclease protection assay. Top, a diagram of the hybrid formed between spliced RNA and DNA oligonucleotide (50 nt) complementary to exons junction. Bottom, A diagram of protected sequences after S1 nuclease digestion. $\mathbf{b}$ Spliced $\left.{ }^{32} \mathrm{P}\right]$-RNA produced in in vitro splicing assay was gel purified as described in Materials and methods. $\left.{ }^{32} \mathrm{P}\right]$-pre-mRNA (negative control) and spliced product [ $\left.{ }^{32} \mathrm{P}\right]-\mathrm{RNA}$ were hybridized to oligo DNA that is complementary to exons junction. Following hybridization, $\left[^{32} \mathrm{P}\right]-\mathrm{RNA}-\mathrm{DNA}$ hybrids were digested with $\mathrm{S} 1$ nuclease that degraded single stranded nucleic acids. The size of the protected region (50 nts) is indicated. Red arrowhead shows protected exon junction sequence in the spliced product

instead resulted in a new RNA band of $\sim 100$ nt (Fig. 4b). These findings further demonstrate that Arabidopsis NE supports pre-mRNA splicing.

\section{Incubation temperature of in vitro splicing reaction affects spliced product}

It has been shown previously that different in vitro splicing reactions have narrow optimum temperatures. The optimum temperature for the mammalian in vitro splicing assay is $30{ }^{\circ} \mathrm{C}$, while for the yeast in vitro splicing system it is $25^{\circ} \mathrm{C}[2,4]$. Therefore, to address the effect of incubation temperature on the accumulation of the spliced product, reactions were carried out at different temperatures: $24,30,37$, and $42{ }^{\circ} \mathrm{C}$ (Fig. 5a). The results showed that $24{ }^{\circ} \mathrm{C}$ is the optimal incubation temperature for high accumulation of the spliced mRNA. The quantity of the spliced product is decreased with increasing

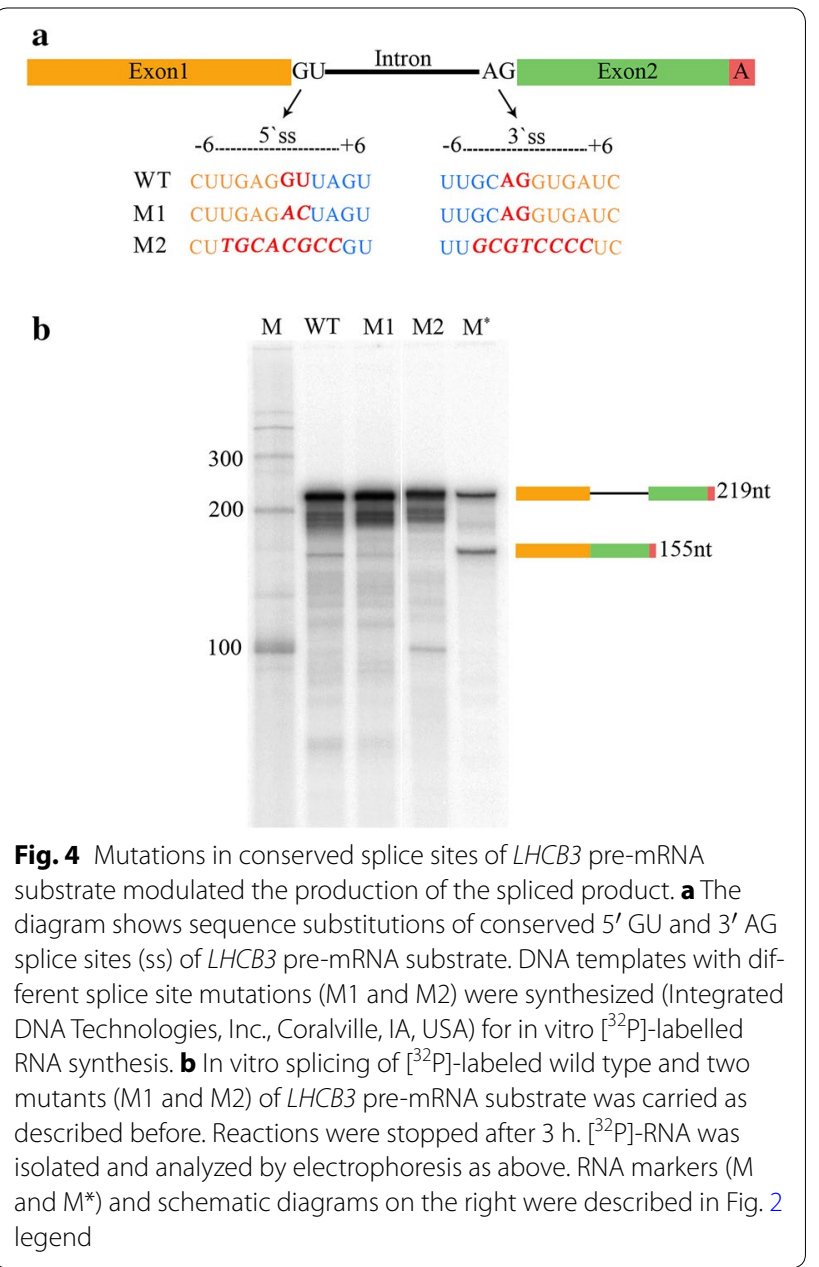

incubation temperature. In fact, the incubation at $42{ }^{\circ} \mathrm{C}$ greatly reduced the appearance of spliced mRNA, suggesting the sensitivity of the reaction to high temperature, as was shown in the previous experiment (Fig. 2b). Thus, these findings indicate that the in vitro splicing assay using Arabidopsis NE has an optimal temperature of $24{ }^{\circ} \mathrm{C}$, and further demonstrate that the NE contains heat-labile components required for generating the spliced product.

\section{Effects of ATP and $\mathrm{Mg}^{2+}$ on pre-mRNA splicing in vitro}

It has been well-established that mammalian, yeast, and Drosophila in vitro splicing reactions require exogenous ATP and $\mathrm{Mg}^{2+}[2,4,5]$. Therefore, we aimed here to investigate and optimize the requirement of these cofactors for the Arabidopsis-derived in vitro splicing reaction. Notably, the NE preparation method does not involve a dialysis step against the swelling buffer, hence the NE contains endogenous concentrations of ATP and $\mathrm{Mg}^{2+}$. In addition, the $25 \mu \mathrm{l}$ in vitro splicing reaction containing 


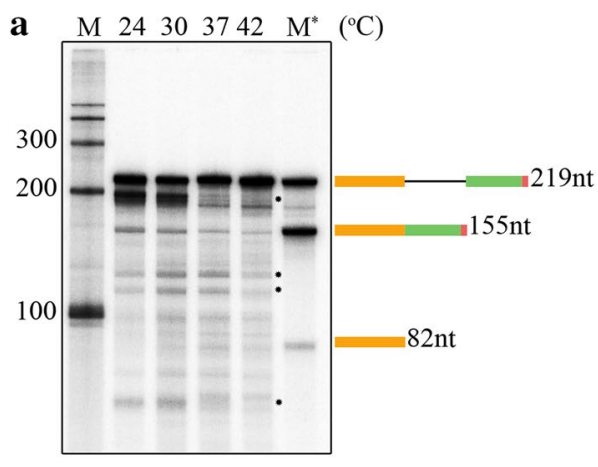

b ATP concentration (mM)
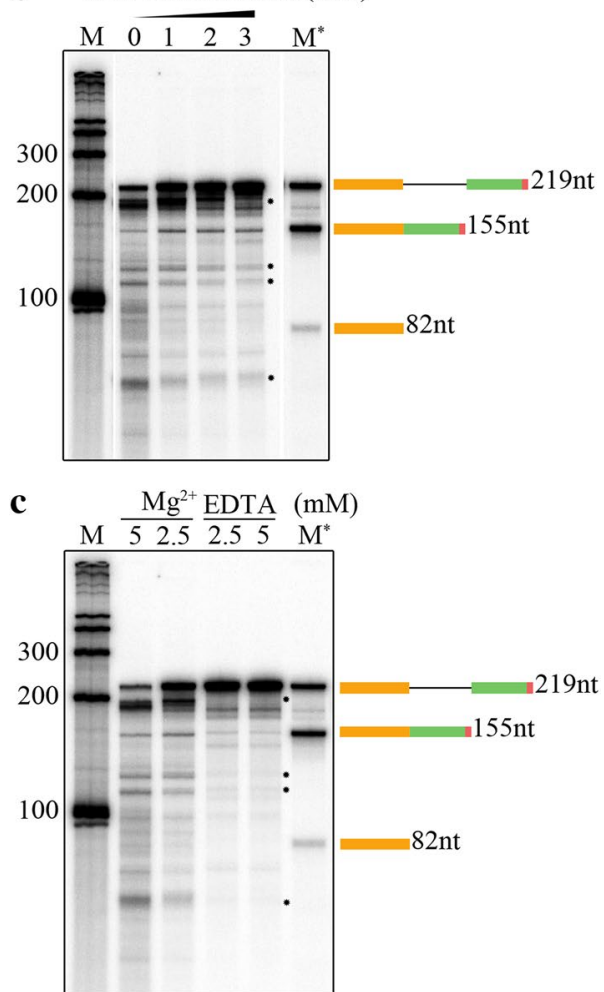

Fig. 5 Analysis of optimum conditions for splicing assay. a The amount of spliced product at different temperatures. In vitro splicing of LHCB3 [32P]-pre-mRNA substrate $(25,000 \mathrm{cpm})$ was carried out as described earlier at different temperatures $\left(24,30,37\right.$, and $\left.40^{\circ} \mathrm{C}\right)$. b Addition of ATP to in vitro splicing assay increased the amount of spliced product from LHCB3 pre-mRNA. c Effect of various concentrations of $\mathrm{Mg}^{2+}$ on the production of the spliced product. In vitro splicing reaction of $\angle H C B 3\left[{ }^{32} \mathrm{P}\right]$-pre-mRNA substrate $(25,000 \mathrm{cpm})$ was performed as described previously with different concentrations of $\mathrm{Mg}^{2+}(2.5$ and $5 \mathrm{mM})$, or in the presence of different concentration (2,5 and $5 \mathrm{mM}$ ) of EDTA, a divalent cation chelator (EDTA). In vitro splicing reaction of $\left.\angle H C B 3{ }^{32} \mathrm{P}\right]$-pre-mRNA substrate $(25,000 \mathrm{cpm})$ was carried out as described above without $(0 \mathrm{mM})$ with increasing concentrations ATP (1,2 and $3 \mathrm{mM})$. All reactions were stopped after $3 \mathrm{~h}$. [32 P]-RNA was recovered and analyzed by electrophoresis on a $6 \%$ polyacrylamide-7 $\mathrm{M}$ urea gel, followed by autoradiography. RNA markers ( $M$ and $M^{*}$ ) and schematic diagrams on the right were described in Fig. 2. The asterisks indicate the potential splicing intermediates. Other [ $\left.{ }^{32} \mathrm{P}\right]$-RNA products could be another pre-mRNA splicing intermediates and/or degradation products
$50 \% \mathrm{NE}$ has $2.5 \mathrm{mM} \mathrm{Mg}^{2+}$, as the swelling buffer contains $5 \mathrm{mM} \mathrm{MgCl}_{2}$.

The ATP concentration of the in vitro splicing reaction was varied while holding the concentrations of remaining components constant (Fig. 5b). In the absence of exogenously added ATP, some RNA degradation was observed. In contrast, the addition of ATP maintained input premRNA integrity and also enhanced production of the spliced mRNA. There were no obvious differences in effect between the ATP concentrations $(1,2$, and $3 \mathrm{mM})$ tested. Therefore, these results indicate that the addition of exogenous ATP might support splicing in vitro, and the optimal concentration is $\sim 1 \mathrm{mM}$.

In the same manner, the effect of varying $\mathrm{Mg}^{2+}$ concentration on the in vitro reaction was investigated (Fig. 5c). We found that $2.5 \mathrm{mM} \mathrm{Mg}^{2+}$ was likely an optimal concentration for the in vitro splicing reaction. Indeed, increasing $\mathrm{Mg}^{2+}$ to $5 \mathrm{mM}$ caused input pre-mRNA instability. On the other hand, in vitro splicing activity was reduced by the addition of 2.5 or $5 \mathrm{mM}$ EDTA, an ion-chelating agent, indicating a divalent cation requirement (Fig. 5c). Taken together, these findings suggest that the plant-derived in vitro splicing reaction is like other in vitro splicing system requires ATP and $\mathrm{Mg}^{2+}$.

\section{Discussion}

In vitro splicing systems derived from mammals, yeast, and Drosophila have allowed remarkable progress in illustrating splicing mechanisms in eukaryotes. There is no in vitro splicing assay for plant systems. Hence, many aspects of pre-mRNA splicing in plants are unknown. In an effort to develop a plant in vitro pre-mRNA splicing system, we report here experimental evidence suggesting that NE derived from Arabidopsis etiolated seedlings is capable of splicing plant pre-mRNA in vitro.

In this study, we show that Arabidopsis NE was able to convert the pre-mRNA of $L H C B 3$ substrate into an expected size of spliced mRNA. The data presented here strongly suggest that the RNA product that corresponds to the spliced mRNA marker is likely a spliced product. Production of the expected size of mRNA upon incubation of pre-mRNA template in the NE, indication that the two exons are linked together according to a junction mapping assay using S1 nuclease, and demonstration that substitution mutations of conserved splice site sequences inhibit the appearance of spliced mRNA-all suggest splicing of $L H C B$ pre-mRNA in plant NE. In addition, we found this system to be similar to the well-established non-plant in vitro pre-mRNA splicing assays in several ways. First, this system is sensitive to high temperature; second, it requires $\mathrm{Mg}^{2+}$; and third, ATP is necessary for the generation of spliced mRNA. From these experiments, we conclude that this is a promising progress 
towards developing an efficient plant in vitro splicing system.

The establishment of an in vitro splicing system for plants has been long overdue; difficulties in developing one may be because of characteristics inherent to plant cells. Our success in establishing this in vitro assay may be attributed to plant materials used for NE preparation, NE preparation method, and choice of pre-mRNA substrate. The NE is prepared from Arabidopsis seedlings that were grown under dark conditions, which are actively growing. The actively growing seedlings have high levels of gene expression for which active premRNA splicing machinery is also needed. Furthermore, unlike other preparation methods that include a high salt lysis buffer, we applied a method that uses low denaturing conditions. This may maintain protein integrity and result in protection of the native states of spliceosomal machinery. Moreover, it is known that not every pre-mRNA substrate can be spliced in vitro, and each substrate requires optimized in vitro splicing conditions [69]. Thus, the choice of pre-mRNA substrate and its primary structure is also a significant factor for successful in vitro splicing systems. In addition, the number and types of splicing factors as well as assay conditions may be different for different pre-mRNAs. We chose LHCB3 pre-mRNA as this gene is highly expressed and is likely to be processed efficiently. In addition to $L H C B 3$, we tested three other plant pre-mRNA substrates (adaptor protein-2 Mu-Adaptin $(A P 2 M)$, TIP41-like protein (TIP41) and polypyrimidine tract-binding protein $1(P T B 1)$ in plant NE with the assay conditions used for $L H C B 3$ pre-mRNA splicing. A schematic diagram and the nucleotides sequences of these pre-mRNAs are provided in Additional file 4: Figure S4A and Additional file 5: Figure S4B, We did not see a spliced product from these pre-mRNAs under the conditions tested (Additional file 6: Figure S5). However, it is likely that different pre-mRNAs require different assay conditions, which need to be optimized for each substrate. In animals also, only a few pre-mRNAs such as $\beta$-globin, $\beta$-tropomyosin, adenovirus, $\delta$-Crystallin, and Simian virus 40 (SV40) pre-mRNA are widely used, suggesting that only a few pre-mRNA are efficiently spliced under in vitro conditions [69-71]. In developing this assay, in our initial trials we used NE from light-grown plants also. However, these extracts showed very little splicing activity with the LHCB3 pre-mRNA (Additional file 7: Figure S6), hence we focused our studies on the NE prepared from the etiolated seedlings in characterizing this system. It is possible that the composition and purity of NE prepared from etiolated and light-grown seedlings is different resulting in differential efficiencies in splicing activity.
Convincing evidence also suggests that the plant in vitro splicing assay system is quite similar to assays used for mammals, yeast, and Drosophila. Similarities involve assay conditions, including concentrations of ATP, $\mathrm{Mg}^{2+}$, and $\mathrm{K}^{+}$[64]. In addition, the time course of a splicing reaction $(0-180 \mathrm{~min})$ is comparable between this in vitro splicing assay and other such systems $[2,4$, 5]. Meanwhile, the optimal incubation temperature for this splicing reaction was unlike other splicing systems; it was within the range of the optimal growth temperature for Arabidopsis $\left(23-25{ }^{\circ} \mathrm{C}\right)$ [72]. Another point of interest is that in vitro splicing of the $L H C B 3$ pre-mRNA substrate generated other RNA species in addition to the spliced RNA. Given the sizes of each part of the premRNA substrate and the production of RNA species within the size range of the intermediates suggest these species are likely splicing intermediates $[6,73]$. In addition, the other RNA species that exhibited unexpected mobility on the gel might correspond to lariat-containing RNA intermediates generated during splicing $[6,73]$. Meanwhile, we cannot rule out the possibility that some of these RNA species might result from degradation of the pre-mRNA substrate. Another point of interest is provided by the observation that substitution mutations of splice site consensus sequences in the $L H C B 3$ pre-mRNA modulate the in vitro splicing reaction. Some early studies using a point mutation strategy in the mammalian in vitro splicing assay have investigated the function of splice site consensus sequences $[68,74]$. Compared with their results, our finding that mutation of the $5^{\prime}$ ss causes reduction of splicing efficiency indicates some similarities between these two systems. Taken together, these findings strongly support that Arabidopsis NE supports in vitro splicing system, which could be used to uncover plant-specific splicing regulatory mechanisms.

The efficiency of splicing in this in vitro system was low. It is worth mentioning that the efficiency of other initial in vitro splicing assays was also low; however, researchers were able to improve the efficiency of in vitro splicing assays over time [71, 75, 76]. Further investigations will be very helpful in gaining more insights for improving the efficiency of this plant in vitro splicing assay. In addition, it is possible that the concentration of some spliceosomal proteins is less than optimum in our NE, leading to low efficiency. In animals, splicing deficient extracts can be made competent by adding one or more splicing factors such as SR proteins $[9,77]$. In future, one could purify one or more SR proteins and supplement the NE or use transgenic lines that are overexpressing one or more SR proteins to prepare $\mathrm{NE}$ to enhance splicing efficiency. 


\section{Conclusions}

In summary, we show that NE derived from Arabidopsis etiolated seedlings is capable of splicing $L H C B 3$ premRNA. This plant-derived in vitro splicing assay system opens new avenues to investigate the spliceosome assembly and composition in plants, splicing regulatory mechanisms specific to plants, and thereby enhance the overall understanding of post-transcriptional gene regulatory mechanisms in eukaryotes.

\section{Additional files}

Additional file 1: Figure S1. Schematic diagram showing the steps in NE preparation from four-day-old Arabidopsis thaliana etiolated seedlings. See "Methods" for details.

Additional file 2: Figure S2. Sequences of DNA template (A), pre-mRNA substrate (B), and predicted mRNA (C). Arabidopsis LHCB3 (AT5G54270) sequence was extracted from The Arabidopsis Information Resource (TAIR). Exonic sequences are shown in upper case letters, while the intron sequence is shown in lower case. SP6 promoter sequence is highlighted in yellow; primers are highlighted in green with either SP6 or adapter sequences: conserved splicing sites (GT-AG) are highlighted in black, and adaptor sequence is highlighted in blue.

Additional file 3: Figure S3. (A) Sequences of wild type (WT) and mutated (mutant 1 and mutant 2) DNA templates used to prepare premRNA substrates. (B) Oligo DNA sequence used for $\mathrm{S} 1$ nuclease assay. Additional file 4: Figure S4. (A) A schematic diagram other Arabidopsis pre-mRNA substrates that were tested for in vitro splicing. Gene names and ID numbers are displayed at the top of each substrate. Introns are black thin lines, first exons are orange boxes, and second exons are green boxes. SP6 promoters are red boxes. Numbers within the boxes or at the top of the introns indicate the length (in nucleotides $(\mathrm{nt})$ ) of each region. Introns' UA content is shown under each intron. The numbers listed on the right indicate the full length of each substrate. The length of exons and introns is drawn to scale.

Additional file 5: Figure S4. (B) Sequences of the other Arabidopsis premRNA substrates tested for in vitro splicing. Sequences were extracted from The Arabidopsis Information Resource (TAIR). Exons are shown in upper case letters, while the introns are shown in lower case. SP6 promoter sequence is highlighted in yellow; primers are highlighted in green, and conserved splicing sites are highlighted in black.

Additional file 6: Figure S5. In vitro splicing assay of different Arabidopsis $\left[{ }^{32} \mathrm{P}\right]$ labeled pre-mRNA substrates. Radiolabelled AP2M, TIP41 and PTB1 pre-mRNA substrates were incubated individually at $30^{\circ} \mathrm{C}$ in the Arabidopsis nuclear extract as described previously. Samples were withdrawn at indicated times, extracted [ $\left.{ }^{32} \mathrm{P}\right]-\mathrm{RNA}$ and analyzed by electrophoresis on a $6 \%$ polyacrylamide-7 $\mathrm{M}$ urea gel, followed by autoradiography. The sizes of the pre-mRNA substrates are indicated at right.

Additional file 7: Figure S6. In vitro splicing assay with the Arabidopsis LHCB3 pre-mRNA substrate using nuclear extract prepared from lightgrown seedlings. Radioactive $\angle H C B 3$ pre-mRNA substrate was synthesized in vitro with a DNA template using SP6 RNA polymerase as described in materials and methods. [ $\left.{ }^{32} \mathrm{P}\right]$-labeled $\angle$ HCB3 pre-mRNA substrate (25,000 cpm) was incubated with nuclear extract from 4 days old Arabidopsis plants grown under light at $30^{\circ} \mathrm{C}$ as described in materials and methods. Samples were withdrawn at intervals $(0,60,90$ and $180 \mathrm{~min})$, $\left.{ }^{32} \mathrm{P}\right]-\mathrm{RNA}$ was extracted and analyzed by electrophoresis on a $6 \%$ polyacrylamide gel containing $7 \mathrm{M}$ urea, The gel was dried and exposed to a phosphor-imaging screen. $M$ indicates [ $\left.{ }^{32} \mathrm{P}\right]$-labeled RNA markers synthesized in vitro using RNA Century ${ }^{\text {TM }}$-Plus Marker Templates (Applied Biosystems, AM7782). $M^{*}$ lane contains [ $\left.{ }^{32} \mathrm{P}\right]$-labeled LHCB3 pre-mRNA and spliced mRNA. Schematic diagrams on the right show pre-mRNA and spliced mRNA.

\section{Abbreviations}

NE: nuclear extract; LHCB3: light-harvesting chlorophyll B-binding protein 3.

\section{Authors' contributions}

ASNR conceived the project. MA and ASNR designed experiments and analyzed the results. MA performed all the experiments. MA and ASNR wrote the manuscript. Both authors read and approved the final manuscript.

\section{Acknowledgements}

The open access publishing fees for this article have been covered in part by the Colorado State University Libraries Open Access Research and Scholarship (OARS) Fund. We thank Dr. Jeffrey Wilusz, Dr. Tai Montgomery and Dr. Asa BenHur for their comments on this work.

\section{Competing interests}

The authors declare that they have no competing interests.

\section{Availability of data and materials}

All the data and the methods used in this study are available in this published article. Any additional information pertinent to this work can be obtained from the corresponding author.

\section{Consent for publication}

The authors give consent to publish this work.

\section{Ethics approval and consent to participate} Not applicable.

\section{Funding}

MA is supported by a scholarship from the government of the Kingdom of Saudi Arabia.

\section{Publisher's Note}

Springer Nature remains neutral with regard to jurisdictional claims in published maps and institutional affiliations.

Received: 31 August 2017 Accepted: 21 December 2017

Published online: 08 January 2018

\section{References}

1. Hernandez N, Keller W. Splicing of in vitro synthesized messenger RNA precursors in HeLa cell extracts. Cell. 1983;35(1):89-99.

2. Krainer AR, Maniatis T, Ruskin B, Green MR. Normal and mutant human beta-globin pre-mRNAs are faithfully and efficiently spliced in vitro. Cell. 1984;36(4):993-1005

3. Padgett RA, Konarska MM, Grabowski PJ, Hardy SF, Sharp PA. Lariat RNA's as intermediates and products in the splicing of messenger RNA precursors. Science. 1984;225(4665):898-903.

4. Lin RJ, Newman AJ, Cheng SC, Abelson J. Yeast mRNA splicing in vitro. J Biol Chem. 1985;260(27):14780-92.

5. Rio DC. Accurate and efficient pre-mRNA splicing in Drosophila cell-free extracts. Proc Natl Acad Sci USA. 1988;85(9):2904-8.

6. Ruskin B, Krainer AR, Maniatis T, Green MR. Excision of an intact intron as a novel lariat structure during pre-mRNA splicing in vitro. Cell. 1984:38(1):317-31.

7. Krainer AR, Maniatis T. Multiple factors including the small nuclear ribonucleoproteins U1 and U2 are necessary for pre-mRNA splicing in vitro. Cell. 1985;42(3):725-36.

8. Black DL, Chabot B, Steitz JA. U2 as well as U1 small nuclear ribonucleoproteins are involved in premessenger RNA splicing. Cell. 1985;42(3):737-50.

9. Krainer AR, Conway GC, Kozak D. Purification and characterization of premRNA splicing factor SF2 from HeLa cells. Genes Dev. 1990;4(7):1158-71. 
10. Screaton GR, Caceres JF, Mayeda A, Bell MV, Plebanski M, Jackson DG, Bell Jl, Krainer AR. Identification and characterization of three members of the human SR family of pre-mRNA splicing factors. EMBO J. 1995;14(17):4336-49.

11. Konarska MM, Sharp PA. Electrophoretic separation of complexes involved in the splicing of precursors to mRNAs. Cell. 1986;46(6):845-55.

12. Das R, Reed R. Resolution of the mammalian E complex and the ATPdependent spliceosomal complexes on native agarose mini-gels. RNA. 1999;5(11):1504-8.

13. Wahl MC, Will CL, Luhrmann R. The spliceosome: design principles of a dynamic RNP machine. Cell. 2009:136(4):701-18.

14. Matera AG, Wang Z. A day in the life of the spliceosome. Nat Rev Mol Cell Biol. 2014;15(2):108-21.

15. Papasaikas P, Valcarcel J. The spliceosome: the ultimate RNA chaperone and sculptor. Trends Biochem Sci. 2016;41(1):33-45.

16. Galej WP, Wilkinson ME, Fica SM, Oubridge C, Newman AJ, Nagai K. CryoEM structure of the spliceosome immediately after branching. Nature. 2016;537(7619):197-201.

17. Yan C, Hang J, Wan R, Huang M, Wong CC, Shi Y. Structure of a yeast spliceosome at 3.6-angstrom resolution. Science. 2015;349(6253):1182-91.

18. Bertram K, Agafonov DE, Liu WT, Dybkov O, Will CL, Hartmuth K, Urlaub H, Kastner B, Stark H, Luhrmann R. Cryo-EM structure of a human spliceosome activated for step 2 of splicing. Nature. 2017;542(7641):318-23.

19. Yan C, Wan R, Bai R, Huang G, Shi Y. Structure of a yeast step II catalytically activated spliceosome. Science. 2017;355(6321):149-55.

20. Fica SM, Oubridge C, Galej WP, Wilkinson ME, Bai XC, Newman AJ, Nagai K. Structure of a spliceosome remodelled for exon ligation. Nature. 2017;542(7641):377.

21. Plaschka C, Lin PC, Nagai K. Structure of a pre-catalytic spliceosome. Nature. 2017;546(7660):617.

22. Reed R, Maniatis T. A role for exon sequences and splice-site proximity in splice-site selection. Cell. 1986;46(5):681-90.

23. Mayeda A, Krainer AR. Regulation of alternative pre-mRNA splicing by hnRNP A1 and splicing factor SF2. Cell. 1992;68(2):365-75.

24. Ge H, Manley JL. A protein factor, ASF, controls cell-specific alternative splicing of SV40 early pre-mRNA in vitro. Cell. 1990;62(1):25-34.

25. Tian M, Maniatis T. Positive control of pre-mRNA splicing in vitro. Science. 1992;256(5054):237-40

26. Liu HX, Zhang M, Krainer AR. Identification of functional exonic splicing enhancer motifs recognized by individual SR proteins. Genes Dev. 1998;12(13):1998-2012.

27. Schaal TD, Maniatis T. Selection and characterization of pre-mRNA splicing enhancers: identification of novel SR protein-specific enhancer sequences. Mol Cell Biol. 1999;19(3):1705-19.

28. Hua Y, Vickers TA, Okunola HL, Bennett CF, Krainer AR. Antisense masking of an hnRNP A1/A2 intronic splicing silencer corrects SMN2 splicing in transgenic mice. Am J Hum Genet. 2008;82(4):834-48.

29. Kaida D, Motoyoshi H, Tashiro E, Nojima T, Hagiwara M, Ishigami K, Watanabe H, Kitahara T, Yoshida T, Nakajima H, et al. Spliceostatin A targets SF3b and inhibits both splicing and nuclear retention of pre-mRNA. Nat Chem Biol. 2007;3(9):576-83.

30. Labadorf A, Link A, Rogers MF, Thomas J, Reddy AS, Ben-Hur A. Genomewide analysis of alternative splicing in Chlamydomonas reinhardtii. BMC Genom. 2010;11:114.

31. Reddy AS. Alternative splicing of pre-messenger RNAs in plants in the genomic era. Annu Rev Plant Biol. 2007;58:267-94.

32. Palusa SG, Ali GS, Reddy AS. Alternative splicing of pre-mRNAs of Arabidopsis serine/arginine-rich proteins: regulation by hormones and stresses. Plant J. 2007:49(6):1091-107.

33. Ali GS, Reddy AS. Regulation of alternative splicing of pre-mRNAs by stresses. Curr Top Microbiol Immunol. 2008;326:257-75.

34. Mazzucotelli E, Mastrangelo AM, Crosatti C, Guerra D, Stanca AM, Cattivelli L. Abiotic stress response in plants: when post-transcriptional and post-translational regulations control transcription. Plant Sci. 2008;174(4):420-31.

35. Lorkovic ZJ. Role of plant RNA-binding proteins in development, stress response and genome organization. Trends Plant Sci. 2009;14(4):229-36.

36. Lee K, Kang H. Emerging Roles of RNA-Binding Proteins in Plant Growth, Development, and Stress Responses. Mol Cells. 2016;39(3):179-85.
37. Staiger D, Brown JW. Alternative splicing at the intersection of biological timing, development, and stress responses. Plant Cell. 2013:25(10):3640-56.

38. Duque P. A role for SR proteins in plant stress responses. Plant Signal Behav. 2011;6(1):49-54

39. Barta A, Marquez Y, Brown JW. Challenges in plant alternative splicing Alternative pre-mRNA Splicing: Theory and Protocols; 2012. p. 79-91.

40. Reddy AS, Marquez Y, Kalyna M, Barta A. Complexity of the alternative splicing landscape in plants. Plant Cell. 2013;25(10):3657-83.

41. Lorković ZJ, Kirk DAW, Lambermon MH, Filipowicz W. Pre-mRNA splicing in higher plants. Trends Plant Sci. 2000;5(4):160-7.

42. Wang BB, Brendel V. The ASRG database: identification and survey of Arabidopsis thaliana genes involved in pre-mRNA splicing. Genome Biol. 2004;5(12):R102.

43. Ru Y, Wang BB, Brendel V. Spliceosomal proteins in plants. Curr Top Microbiol Immunol. 2008:326:1-15.

44. Koncz C, Dejong F, Villacorta N, Szakonyi D, Koncz Z. The spliceosomeactivating complex: molecular mechanisms underlying the function of a pleiotropic regulator. Front Plant Sci. 2012;3:9.

45. Brown JW, Feix G, Frendewey D. Accurate in vitro splicing of two pre-mRNA plant introns in a HeLa cell nuclear extract. EMBO J. 1986:5(11):2749-58.

46. Hartmuth $\mathrm{K}$, Barta A. In vitro processing of a plant pre-mRNA in a HeLa cell nuclear extract. Nucleic Acids Res. 1986;14(19):7513-28.

47. Barta A, Sommergruber K, Thompson D, Hartmuth K, Matzke MA, Matzke MA. The expression of a nopaline synthase-human growth hormone chimeric gene in transformed tobacco and sunflower callus tissue. Plant Mol Biol. 1986;6:347-57.

48. Haseloff J, Siemering KR, Prasher DC, Hodge S. Removal of a cryptic intron and subcellular localization of green fluorescent protein are required to mark transgenic Arabidopsis plants brightly. Proc Natl Acad Sci USA 1997;94(6):2122-7.

49. Weibauer K, Herrero J-J, Filipowicz W. Nuclear pre-mRNA processing in plants: distinct modes of $3^{\prime}$ splice site selection in plants and animals. Mol Cell Biol. 1988;8:2042-51.

50. Baynton CE, Potthoff SJ, McCullough AJ, Schuler MA. U-rich tracts enhance $3^{\prime}$ splice site recognition in plant nuclei. Plant J. 1996;10(4):703-11.

51. McCullough AJ, Schuler MA. Intronic and exonic sequences modulate 5' splice site selection in plant nuclei. Nucleic Acids Res. 1997;25(5):1071-7.

52. Schuler MA. Splice site requirements and switches in plants. Curr Top Microbiol Immunol. 2008:326:39-59.

53. Ner-Gaon H, Halachmi R, Savaldi-Goldstein S, Rubin E, Ophir R, Fluhr R. Intron retention is a major phenomenon in alternative splicing in Arabidopsis. Plant J. 2004;39(6):877-85.

54. Syed NH, Kalyna M, Marquez Y, Barta A, Brown JW. Alternative splicing in plants-coming of age. Trends Plant Sci. 2012;17(10):616-23.

55. Kim E, Magen A, Ast G. Different levels of alternative splicing among eukaryotes. Nucleic Acids Res. 2007;35(1):125-31.

56. Sugiura M. Plant in Vitro Transcription Systems. Annu Rev Plant Physiol Plant Mol Biol. 1997:48:383-98.

57. Lou H. A journey. RNA. 2015;21(4):681-2.

58. Folta KM, Kaufman LS. Isolation of Arabidopsis nuclei and measurement of gene transcription rates using nuclear run-on assays. Nat Protoc. 2006:1(6):3094-100

59. Kataoka N, Dreyfuss G. Preparation of efficient splicing extracts from whole cells, nuclei, and cytoplasmic fractions. Methods Mol Biol. 2008;488:357-65

60. Xing D, Wang Y, Hamilton M, Ben-Hur A, Reddy AS. Transcriptome-wide identification of RNA targets of Arabidopsis SERINE/ARGININE-RICH45 uncovers the unexpected roles of this RNA binding protein in RNA processing. Plant Cell. 2015;27(12):3294-308.

61. Palusa SG, Reddy AS. Analysis of RNA-protein interactions using electrophoretic mobility shift assay (gel shift assay). Bio protocol. 2013;22(3):1-10.

62. Movassat M, Mueller WF, Hertel KJ. In vitro assay of pre-mRNA splicing in mammalian nuclear extract. Methods Mol Biol. 2014;1126:151-60.

63. Dupuy B, Sonenshein AL. Regulated transcription of Clostridium difficile toxin genes. Mol Microbiol. 1998;27(1):107-20. 
64. Hicks MJ, Lam BJ, Hertel KJ. Analyzing mechanisms of alternative premRNA splicing using in vitro splicing assays. Methods. 2005;37(4):306-13.

65. Watson JC, Thompson WF. Purification and restriction endonuclease analysis of plant nuclear-DNA. Method Enzymol. 1986;118:57-75.

66. Lin RJ, Lustig AJ, Abelson J. Splicing of yeast nuclear pre-mRNA in vitro requires a functional 405 spliceosome and several extrinsic factors. Genes Dev. 1987;1(1):7-18.

67. Shukla RR, Dominski Z, Zwierzynski T, Kole R. Inactivation of splicing factors in HeLa cells subjected to heat shock. J Biol Chem. 1990;265(33):20377-83.

68. Aebi M, Hornig H, Weissmann C. $5^{\prime}$ cleavage site in eukaryotic pre-mRNA splicing is determined by the overall $5^{\prime}$ splice region, not by the conserved 5' GU. Cell. 1987;50(2):237-46.

69. Mayeda A, Krainer AR. Mammalian in vitro splicing assays. Methods Mol Biol. 1999;118:315-21.

70. Padgett RA, Hardy SF, Sharp PA. Splicing of adenovirus RNA in a cell-free transcription system. Proc Natl Acad Sci USA. 1983;80(17):5230-4.

71. Reichert $\mathrm{V}$, Moore MJ. Better conditions for mammalian in vitro splicing provided by acetate and glutamate as potassium counterions. Nucleic Acids Res. 2000;28(2):416-23.
72. Rivero L, Scholl R, Holomuzki N, Crist D, Grotewold E, Brkljacic J. Handling Arabidopsis plants: growth, preservation of seeds, transformation, and genetic crosses. Methods Mol Biol. 2014;1062:3-25.

73. Padgett RA, Grabowski PJ, Konarska MM, Seiler S, Sharp PA. Splicing of messenger RNA precursors. Annu Rev Biochem. 1986;55:1119-50.

74. Aebi M, Hornig H, Padgett RA, Reiser J, Weissmann C. Sequence requirements for splicing of higher eukaryotic nuclear pre-mRNA. Cell. 1986;47(4):555-65.

75. Kole $R$, Weissman SM. Accurate in vitro splicing of human beta-globin RNA. Nucleic Acids Res. 1982;10(18):5429-45.

76. Goldenberg CJ, Hauser SD. Accurate and efficient in vitro splicing of purified precursor RNAs specified by early region 2 of the adenovirus 2 genome. Nucleic Acids Res. 1983;11(5):1337-48.

77. Mayeda A, Krainer AR. Preparation of HeLa cell nuclear and cytosolic S100 extracts for in vitro splicing. Methods Mol Biol. 1999;1 18:309-14.

\section{Submit your next manuscript to BioMed Central and we will help you at every step:}

- We accept pre-submission inquiries

- Our selector tool helps you to find the most relevant journal

- We provide round the clock customer support

- Convenient online submission

- Thorough peer review

- Inclusion in PubMed and all major indexing services

- Maximum visibility for your research

Submit your manuscript at www.biomedcentral.com/submit 